\title{
Delineation of leachate at a dumpsite using geo-electrical resistivity method: a case study of Abule Egba, Lagos, Nigeria
}

\author{
Oluwafemi Olutayo Okunowo ${ }^{1}$. Oluwakemi Yemisi Adeogun ${ }^{1} \cdot$ Kehinde Saheed Ishola ${ }^{1} \cdot$ Saheed Alli $^{1}$
}

Received: 1 May 2020 / Accepted: 22 September 2020 / Published online: 12 December 2020

(c) Springer Nature Switzerland AG 2020

\begin{abstract}
This study presents the application of the dipole-dipole and the Schlumberger electrode arrays of electrical resistivity techniques to map the extent of leachate migration and its possible impact on groundwater at Abule Egba, dumpsite, Lagos. The uncontrolled mode of refuse disposal in Lagos over the years is worrisome because it reduces the potential sources of potable water for the growing population. This informed the evaluation of leachate migration to groundwater in the study area. To achieve this, 2-D resistivity imaging data was acquired along five traverses and was integrated with VES data acquired along the established traverses. The 2-D resistivity imaging and VES data were processed using DIPPRO and WINRESIST software respectively. The interpretation of the geo-electrical measurements was constrained by borehole data obtained within the study area. The results of the 2D and VES revealed five (5) geoelectric layers which correspond to the topsoil, clay, sandy clay, clayey sand and sand. The topsoil has layer thickness of $0.5-2.7 \mathrm{~m}$ and resistivity values within range of $9.8-133.3 \Omega \mathrm{m}$. The clay has layer thicknesses between $1.7 \mathrm{~m}$ to $33.1 \mathrm{~m}$ and resistivity values ranging from 4.8 to $67.9 \Omega \mathrm{m}$. The sandy clay layer has thickness of $1.0-14.5 \mathrm{~m}$ and resistivity values ranging from 13.5 to $128.8 \Omega \mathrm{m}$. The clayey sand layer has thickness $1.9-44.4 \mathrm{~m}$ and resistivity values ranging from 16.3 to $129.0 \Omega \mathrm{m}$. The sand delineated has thickness of 5.7-81.7 $\mathrm{m}$ and resistivity values ranging from 1.9 to $1230 \Omega \mathrm{m}$. The fourth layer with low resistivity values of 1.9-2.4 $\Omega \mathrm{m}$ at depth range $14.5-29 \mathrm{~m}$ is suggestive of leachate contamination when compared with the delineated sand of resistivity values of 419-916 $\Omega \mathrm{m}$ in VES 19-24 which serve as control. The study revealed that some regions around the dumpsite have been contaminated by leachate which could infiltrate to the unconfined aquifers in the area if not properly monitored and regulated. Thus, this study shows the efficacy of electrical resistivity method in mapping leachate generated from solid wastes in the dumpsite.
\end{abstract}

Keywords Dumpsite · Leachate contamination · Groundwater · Electrical resistivity · Clay · Aquifer

\section{Introduction}

Dumpsites have been recognized as one of the major threat to groundwater resources [18]. The volume of wastes generated daily across Lagos metropolis is on the increase and presently it is estimated to about 1000 Tons per day apart from the medical wastes which is given separate and special treatment [16]. The quantity and quality of municipal solid waste (MSW) generated depends upon some factors such as population, life style, food habit, standard of living, industrial and commercial activities as well as climate [5]. The solid wastes dumped, gradually release its initial interstitial water called leachate and some of its decomposed by-products might settle at the bottom of the wastes and later percolates through the soil into the groundwater [19]. The leachate usually contains

Electronic supplementary material The online version of this article (https://doi.org/10.1007/s42452-020-03573-6) contains supplementary material, which is available to authorized users.

Oluwafemi Olutayo Okunowo, oluwafemiokunowo96@gmail.com | 'Department of Geosciences, University of Lagos, Lagos, Nigeria. 
mainly organic carbon in the form of fulvic acids, which contains toxic substances, especially, when the wastes are of industrial origin [17]. Such contamination of groundwater resource poses a substantial risk to the numerous users for domestic and industrial activities as well as the ecosystem. Every year, about two million people die due to poor environmental sanitation and consumption of contaminated water, of which ninety percent $(90 \%)$ are children [22].

Groundwater could be polluted at times due to the percolation of water from dumpsite, thereby making it unsuitable for drinking [19]. The characteristics and volume of leachate produced in a dumpsite depend on the composition of waste materials, source of the waste, availability of moisture, and the local temperature conditions. Most of the wastes deposited at the Abule Egba Dumpsite are from domestic and industrial activities. Leachate is regarded as worst source of shallow aquifer contamination [19]. The migration of the leachate plume can also pollute the aquifers and surface waters over a long duration consequently leading to serious health and environmental risks [28]. The cheap mode of disposal of huge refuse in Lagos over the years is worrisome because it reduces the potential sources of potable water for the growing population [6].

In the last two decades, many studies have been carried out with respect to dumpsites investigation using different techniques. Remote sensing and Geographical Information System have been applied in mapping potential dumpsites $[10,11,13,14]$. The usefulness of surface geophysical methods for solving a number of problems in dumpsite investigations has continued to receive considerable attention. Geophysical methods such as Electrical resistivity [21, 23, 25] Induced Polarization [9], Seismic Refraction, Ground penetrating radar [30] among others have been used in a number of years for pollution and environmental studies. The electrical resistivity method however, has been found very suitable for dumpsite characterization and evaluation. This is because it is cheap, non- invasive, fast and provides good electrical resistivity contrast between the target of interest and the host material [4-6]. The technique has proven effective to map the distribution of leachate likewise monitor its possible migration pattern in the soil $[8,14]$. Traditional methods like chemical analysis, hydrological and geophysical techniques could be used for the identification and delineation of contaminant plume $[9,29,30]$.

The applications of integrated studies have been advocated for a comprehensive dumpsite characterization. This becomes necessary as different techniques complement one another. For instance, in a situation where low resistivity signatures are suspected which could be caused by leachate, salt water intrusion, clay sediment, peat, or shale formation. In this study, direct borehole data was used to constrain the interpretation of electrical resistivity data in order to differentiate clay from leachate plume. A number of studies have been carried out to map possible areas for groundwater development that will be free from contaminants. The low resistivity responses of the underlying aquifer was attributed to possible contamination from the dumpsite $[2,25]$. According to $[24,25]$ the hydrological systems of Abule Egba are vulnerable to contamination particularly around dumpsite facilities. This necessitates a periodic assessment and evaluation of leachate migration to ground water systems in Abule Egba dumpsite with a view to protecting the many people residing around the dumpsite. In view of this, the 2-D electrical resistivity method and vertical electrical sounding (VES) techniques were selected for a good resolution and proper mapping of the leachate within the study area.

\section{Materials and methods}

\subsection{The study area}

Abule Egba dumpsite occupies a land area of about 10.2 hectares in the western part of Lagos in Alimoso Local Government and receives waste from the densely populated area [16]. The dumpsite was not active since 2008 but re-opened in 2018 [16]. It lies between longitudes $03^{\circ} 17^{\prime} \mathrm{E}$ and $03^{\circ} 19^{\prime} \mathrm{E}$ and latitudes $06^{\circ} 37^{\prime} \mathrm{N}$ and $06^{\circ} 39^{\prime} \mathrm{N}$. The dumpsite receives an average of about $1864.29 \mathrm{~m}^{3}$ of waste per day [16]. It lies within Lagos state. Lagos State is a sedimentary terrain located within the western part of Nigeria (Electronic Supplementary Material) a zone made of coastal creek and lagoon [7]. The area is also developed by barrier beaches associated with sand deposition [13]. Lagos is underlain by the Dahomey Basin. The Dahomey Basin is a combination of inland/coastal/offshore basin that stretches from southeastern Ghana through Togo and the Republic of Benin to southwestern Nigeria (Electronic Supplementary Material). Exposed geological formation reveals that the lithological units are mainly of sands, clays, their intercalations and limestone [6]. Several notable researchers have described the stratigraphy of the Dahomey Basin particularly southwestern part of Nigeria where the study lies to consist of Abeokuta group (Ise, Afowo and Araromi Formations), Ewekoro, Oshosun, and Ilaro Formations and Benin formation (coastal plain sands) [7].

Abule Egba area of Lagos consists of unfossilifereous sandstone and gravels weathered from underlying Precambrian basement. Earlier literature on the hydrogeology of the area has shown that the sands of Abeokuta Group, coastal plain sands and recent sediment constitute the aquifer units. 


\subsection{Data acquisition}

The electrical resistivity survey was carried out along five traverses with spread length of $100 \mathrm{~m}$ each using 2D electrical imaging and VES techniques. This was carried out to reveal the lateral and vertical variation of resistivity values beneath the dumpsite. The resistivity data was acquired using the Pasi Terrameter. The other accessories were four (4) electrodes, measuring tape, four reels of cables, Garmin Global Positioning System (GPS). For the $2 \mathrm{D}$ resistivity measurements, the dipole-dipole array was deployed due to its greater depth of investigation, good horizontal resolution and data coverage [15]. The data was acquired with minimum electrode spacing of $5 \mathrm{~m}$ and inter-electrode spacing ranging from 5 to $90 \mathrm{~m}$. The spread of the traverses was based on the available space around the dumpsite (Electronic Supplementary Material). The co-ordinates of locations of measurements were recorded with GPS.

In order to have good insight into the variation of resistivity with depth in the study area, thirty (30) VES was acquired along the five (5) traverses using the schlumberger electrode array for maximum current penetration into the subsurface. The current electrode spacing (AB) ranges from a minimum of $2.0 \mathrm{~m}$ to a maximum of $400 \mathrm{~m}$. The sounding points were selected at $30 \mathrm{~m}, 40 \mathrm{~m}, 50 \mathrm{~m}$, $50 \mathrm{~m}, 60 \mathrm{~m}, 70 \mathrm{~m}$, and $80 \mathrm{~m}$ along the established five (5) traverses (Electronic Supplementary Material).

\subsection{Data processing}

The 2D field resistivity data was obtained using Eq. (1)

$\rho_{\alpha}=\pi(n+1)(n+2) a \frac{V}{l}$

where $n=$ number of electrode spacing, $a=$ electrode separation, $V=$ resulting electric potential $I=$ current injected.

The inverted resistivity models were generated after three iterations using DIPRO ${ }^{\mathrm{tm}} 4.0$ inversion software. This was to ensure that the inversion models were not smoothened out as such represent the geology of the study area. For the VES data, the quantitative interpretation of the depth sounding curves was carried out by partial curve matching technique [15]. The apparent resistivity values were estimated using the Eq. (2)

$\rho_{\alpha}=\pi \frac{L^{2}-I^{2}}{2 l} \frac{V}{l}$

where $K=\pi \frac{L^{2}-I^{2}}{2 I}$
$K=$ geometric factor of the electrode arrangement, hence the Eq. (2) can be re-written as (4)

$\rho_{\alpha}=K \frac{V}{l}$

where $\rho_{\alpha}=$ apparent resistivity, $L=$ potential electrode spacing, $I=$ current electrode spacing.

The apparent resistivity values (obtained by multiplying the resistance measured with the geometry factor of the schlumberger array) were plotted against half electrode spacing on a log-log graph using transparent paper. The partial curve matching technique involved the use of the standard two (2) layers Master curves and four (4) auxiliary curve types $(H, K, A$, and $Q)[15,27]$. This procedure required segment by segment curve matching, starting from the position with shortest half electrode spacing to the maximum. The VES curves obtained from the partial curve matching were used as the input parameters during the inversion process using WINRESIST 1.0 version software. To obtain an optimal model of the earth, the iteration was set at three [31]. This reduces overestimation of depth. The results of the computer aided iteration process are presented as inverted VES curves. The Geoelectric sections were generated using AUTOCAD software.

\section{Results}

\subsection{D electrical resistivity imaging results}

The inverted resistivity section is shown in Fig. 1a-e. The resistivity section along traverse one shows that four layers are clearly delineated (Fig. 1a). The layers are topsoil, clay, sand (impregnated with leachate), clayey sand and sand. The resistivity of the topsoil (orange-purple colour) varies from 13 to $54 \Omega \mathrm{m}$. The high resistivity value $(54 \Omega \mathrm{m})$ of the topsoil (purple) is an indication of the presence of non-conductive and non-biodegradable waste materials. The clay delineated has resistivity values ranging from 7.3 to $14 \Omega \mathrm{m}$. The sand (impregnated leachate) with resistivity values ranging from 1.1 to $2.1 \Omega \mathrm{m}$ is mapped at $20-35 \mathrm{~m}$, 45-55 $\mathrm{m}$ and $60-70 \mathrm{~m}$. Clayey sand (yellow colour) with resistivity values ranging from 13 to $54 \Omega \mathrm{m}$ is delineated. The resistivity values of sand vary from $(33-88 \Omega \mathrm{m})$. This result has good correlation with the results of the VES along same traverse. The low resistivity values associated with the sand $(33-88 \Omega \mathrm{m})$ is indicative of contamination when compared with borehole log information.

Figure $1 \mathrm{~b}$ shows the $2 \mathrm{D}$ electrical resistivity structure along traverse two. The resistivity values vary from 3.2 to $510 \Omega \mathrm{m}$. The layers delineated are topsoil, clay and sand. The resistivity of the topsoil ranging from ( 23 to $80 \Omega \mathrm{m})$. The high resistivity $(80 \Omega \mathrm{m})$ of topsoil at spread 


\section{TRAVERSE ONE (2-D Resistivity Structure)}

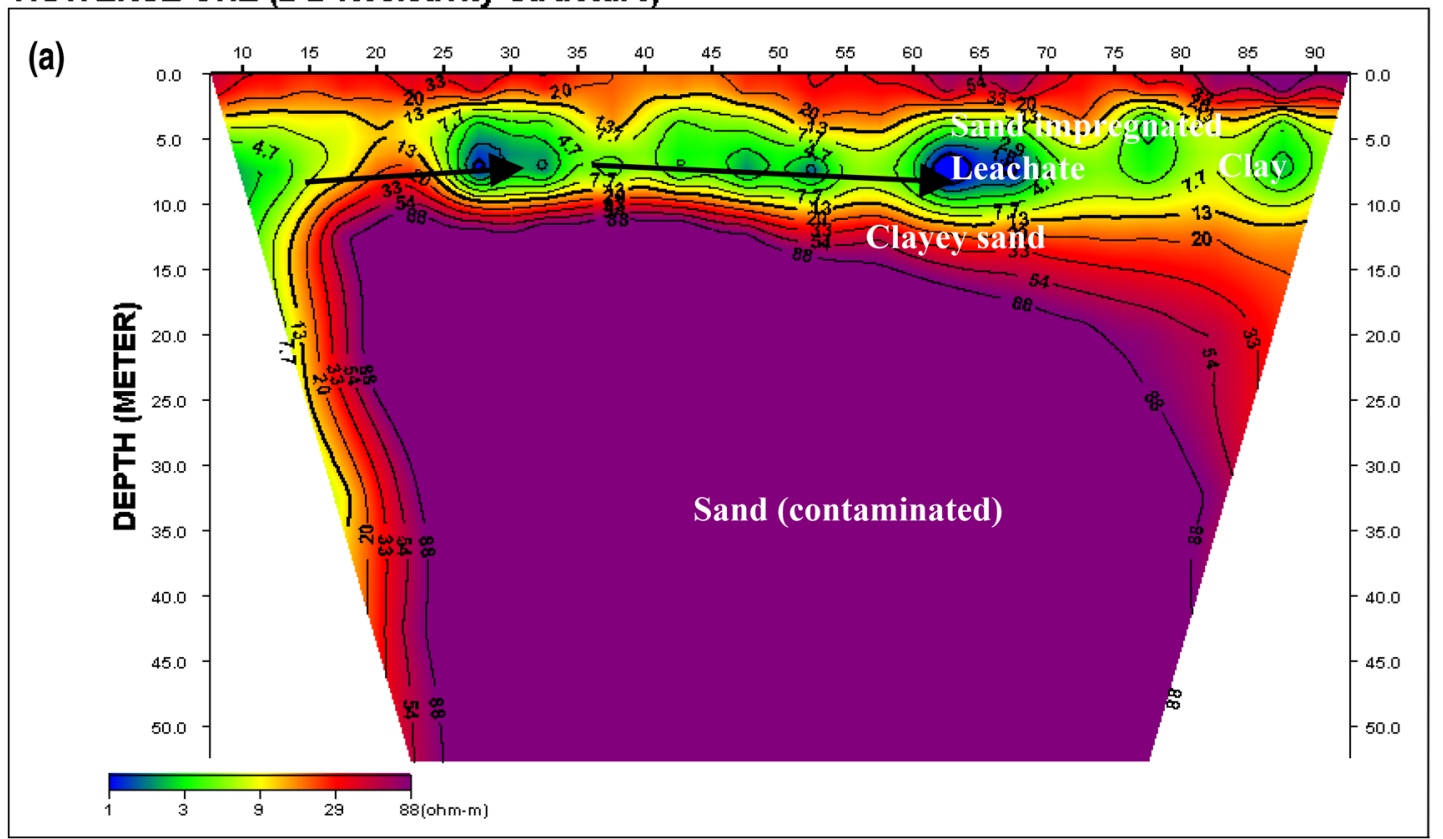

TRAVERSE 2 (2-D Resistivity Structure)

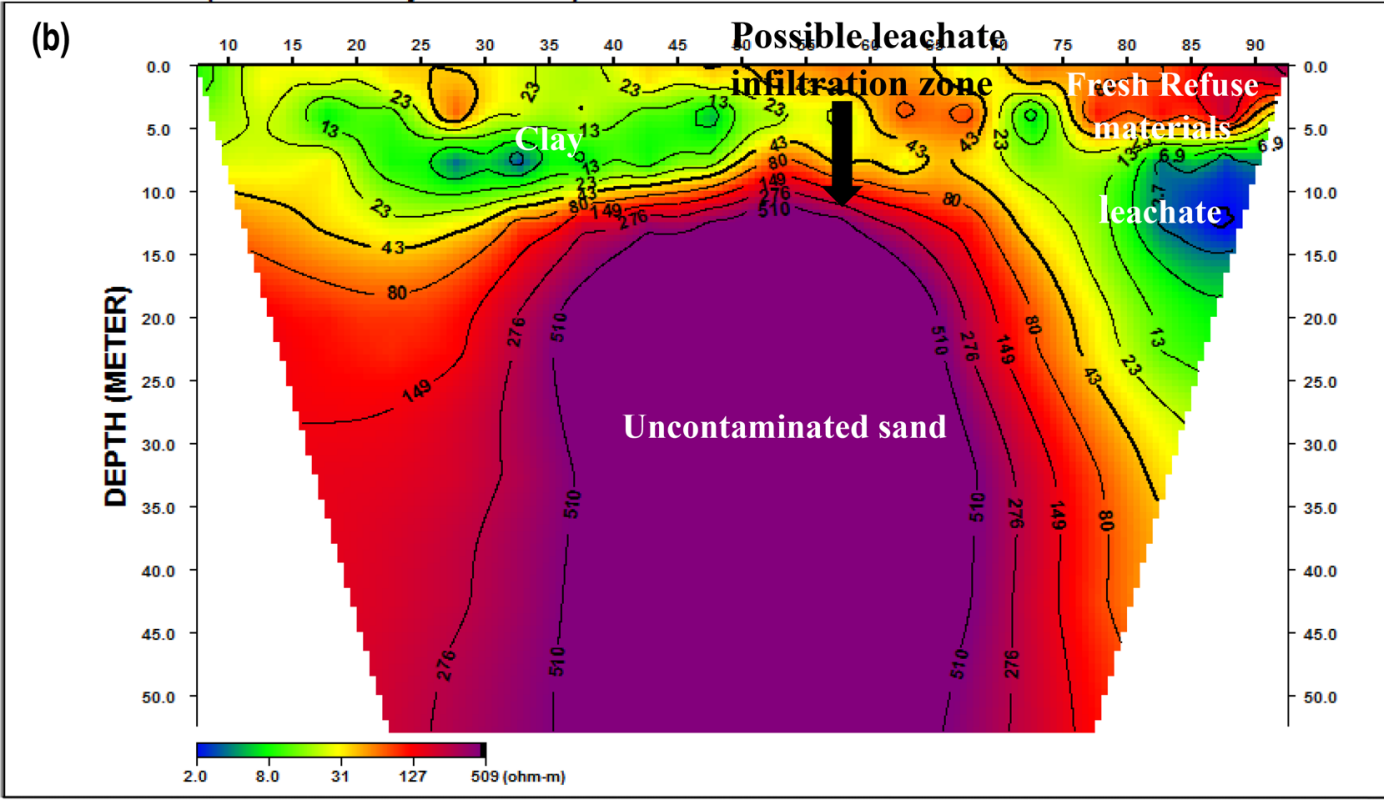

Fig. 1 a 2D Resistivity Structure along Traverse one. b 2D Resistivity Structure along Traverse two. c 2D Resistivity Structure along Traverse three. d 2D Resistivity Structure along Traverse four. e 2D Resistivity Structure along Traverse five

$(75-100 \mathrm{~m})$ is an indicative of fresh refuse or non -biodegradable material. The clay (green colour) with resistivity values ranging from (13-23 $\Omega \mathrm{m}$ ) extent laterally across the traverse but replaced by clayey sand/sandy clay (resistivity value ranging from 43 to $80 \Omega \mathrm{m}$ ) at spread (50 to $70 \mathrm{~m}$ ). The clayey sand/sandy clay is vulnerable to leachate infiltration. The thick clay $(13 \mathrm{~m})$ served as protective layer impeding leachate into the sand. Leachate (resistivity $3.2 \Omega \mathrm{m}$ ) is mapped at spread $(80-100 \mathrm{~m})$ depth $(5.0-15.0 \mathrm{~m})$. The sand delineated has resistivity value range from $(279.0-510 \Omega \mathrm{m})$. The high resistivity value of sand is an indication of non-contamination. 

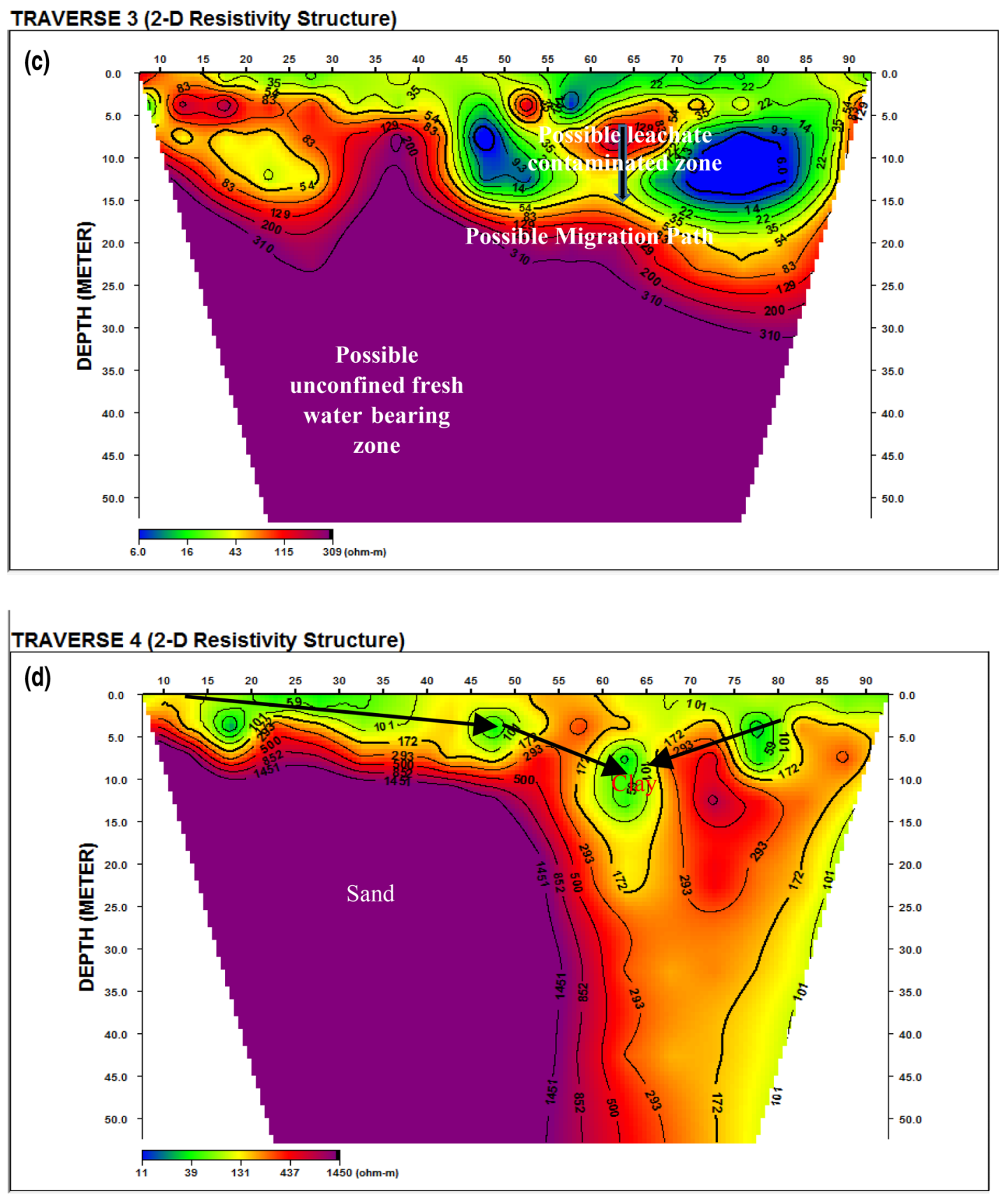

Fig. 1 (continued)

A depth of $50 \mathrm{~m}$ was probed with resistivity ranging from 6.4 to $310 \Omega \mathrm{m}$ along traverse three (Fig. 1c). The lithological units delineated are topsoil, sandy clay, clayey sand, sand and sand (impregnated with leachate). The topsoil has resistivity values ranging from 22 to $35 \Omega \mathrm{m}$. The resistivity values of clayey sand/sandy clay (orange or yellow colour) ranging from 21 to $70 \Omega \mathrm{m}$. The resistivity values of sand (purple colour) ranging from 80 to $310 \Omega \mathrm{m}$. The clayey sand (yellow colour) is the possible layer through which leachate may percolate into the fresh water bearing zone. Along the lateral distance between 45 and $85 \mathrm{~m}$, this zone is suspected to be contaminated by leachate (blue colour) with low resistivity value of $6.0 \Omega \mathrm{m}$.

Figure $1 \mathrm{~d}$ is the inverted resistivity section along traverse four. The resistivity values for this section range from 56 to $1451 \Omega \mathrm{m}$ (Fig. 1d). The lithological units delineated correspond to topsoil, clay, sandy clay and sand. The topsoil is heterogeneous, it composes of clay (resistivity values ranges from 10 to $59 \Omega \mathrm{m}$ ) and sandy clay (resistivity values ranging from 101 to $172 \Omega \mathrm{m}$ ). The clay delineated 


\section{TRAVERSE 5 (2-D Resistivity Structure)}

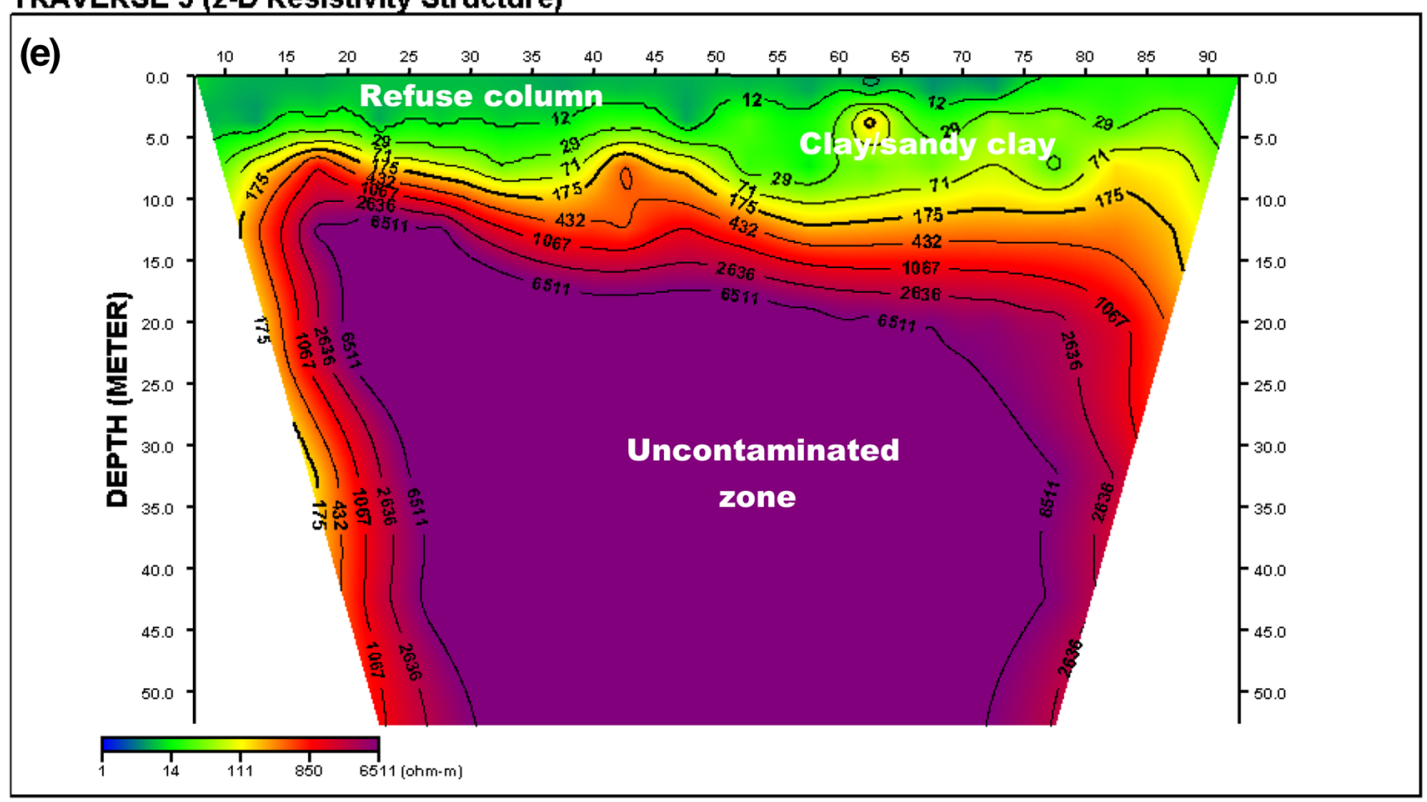

Fig. 1 (continued)

is pocket like structure dispersed within the area at shallow depth of about $10 \mathrm{~m}$. The traverse is characterized by sand (purple) and clayey sand (orange). The resistivity of clayey sand ranging from 10.0 to $172.0 \Omega \mathrm{m}$ while that of sand ranging from 293 to $1451 \Omega \mathrm{m}$. The high resistivity values $(293-1451 \Omega \mathrm{m})$ associated with sand is indicative of no contamination.

The traverse five (Fig. 1e) was acquired on fresh refuse dumped on the site. The lithological units delineated are topsoil, clay, sandy clay and sand. The topsoil soil composes of decomposed refuse (light blue colour) with resistivity of $12 \Omega \mathrm{m}$. The clay/sandy clay (light green colour) has resistivity range from 29 to $71 \Omega \mathrm{m}$. The clayey sand (yellow colour) has resistivity values ranging from 71 to $432 \Omega \mathrm{m}$. The resistivity of sand ranges from 175 to 6500 $\Omega \mathrm{m}$. The high resistivity value of sand is an indication of no leachate plume.

\subsection{D VES geo-resistivity sections}

The representative of the resistivity curves generated are shown in Fig. 2a, b. The two interpreted VES curves (QQH) show that five layers earth model are obtained. The geoelectric sections generated from the results of VES curves are displayed in Fig. 3a-e.

Figure 3a shows the geoelectric section along $\mathrm{AA}^{\prime}$ consisting of VES (1-6). The resistivity section reveals four to five geo-electric layers. The layers consist of topsoil, sandy clay, sand (impregnated with leachate), clayey sand and sand. The first layer constitutes the topsoil with resistivity values ranging from 39.6 to $90.0 \Omega \mathrm{m}$ and thickness $0.5-0.8 \mathrm{~m}$. The second layer composes of sandy clay with resistivity values ranging from 13.5-64.7 $\Omega \mathrm{m}$ and thickness range $2.1-4.0 \mathrm{~m}$. The third stratum is clay with resistivity values $5.2-12.9 \Omega \mathrm{m}$, and thickness range 5.3-16.2 m. The fourth layer is made of sand (impregnated with leachate) with resistivity values ranging from 1.9 to $2.4 \Omega \mathrm{m}$ to a depth of about $29.0 \mathrm{~m}$. VES (4 and 6) composed of clayey sand with resistivity values of $53.5 \Omega \mathrm{m}$ and $24 \Omega \mathrm{m}$ respectively. The presence of thick layer of clay (about $16.2 \mathrm{~m}$ ) in layer three (3) of VES (4 and 6) is probably responsible for the absence of leachate. The thickness of fourth layer in VES 6 is $32.0 \mathrm{~m}$, and it could not be ascertained in VES 4 because current terminated within this zone. The fifth horizon signifies clayey/sand with resistivity values ranges from 16.3 to $88 \Omega \mathrm{m}$ but the thickness could not be ascertained because current terminated within this zone. The low resistivity values $(16.3-88 \Omega \mathrm{m})$ of sand is indicative of contamination.

Figure $3 \mathrm{~b}$ consists of VES (7-12). The geoelectric section reveals four to five layers namely topsoil, clay/sandy clay, clayey sand and sand. Beneath VES 8, 9, 11 and 12 there are five layers while VES 7 and VES 10 there are four layers. The topsoil is characterized by resistivity values ranging from 10.2 to $75.1 \Omega \mathrm{m}$, and thickness ranging from 0.5 to $0.9 \mathrm{~m}$. The second layer composes of sandy clay/clayey sand with resistivity $37.1-135.3 \Omega \mathrm{m}$ and thickness range from 1.9 to $6.5 \mathrm{~m}$. VES 11 has the highest resistivity of $135.3 \Omega \mathrm{m}$. The third layer of VES 7, 8, 10 and 12 composes of clay with thickness ranges from 5.7 to $33.5 \mathrm{~m}$. Beneath VES 9 and 
Fig. 2 a Resistivity curve for VES 1. b Resistivity curve for VES 2
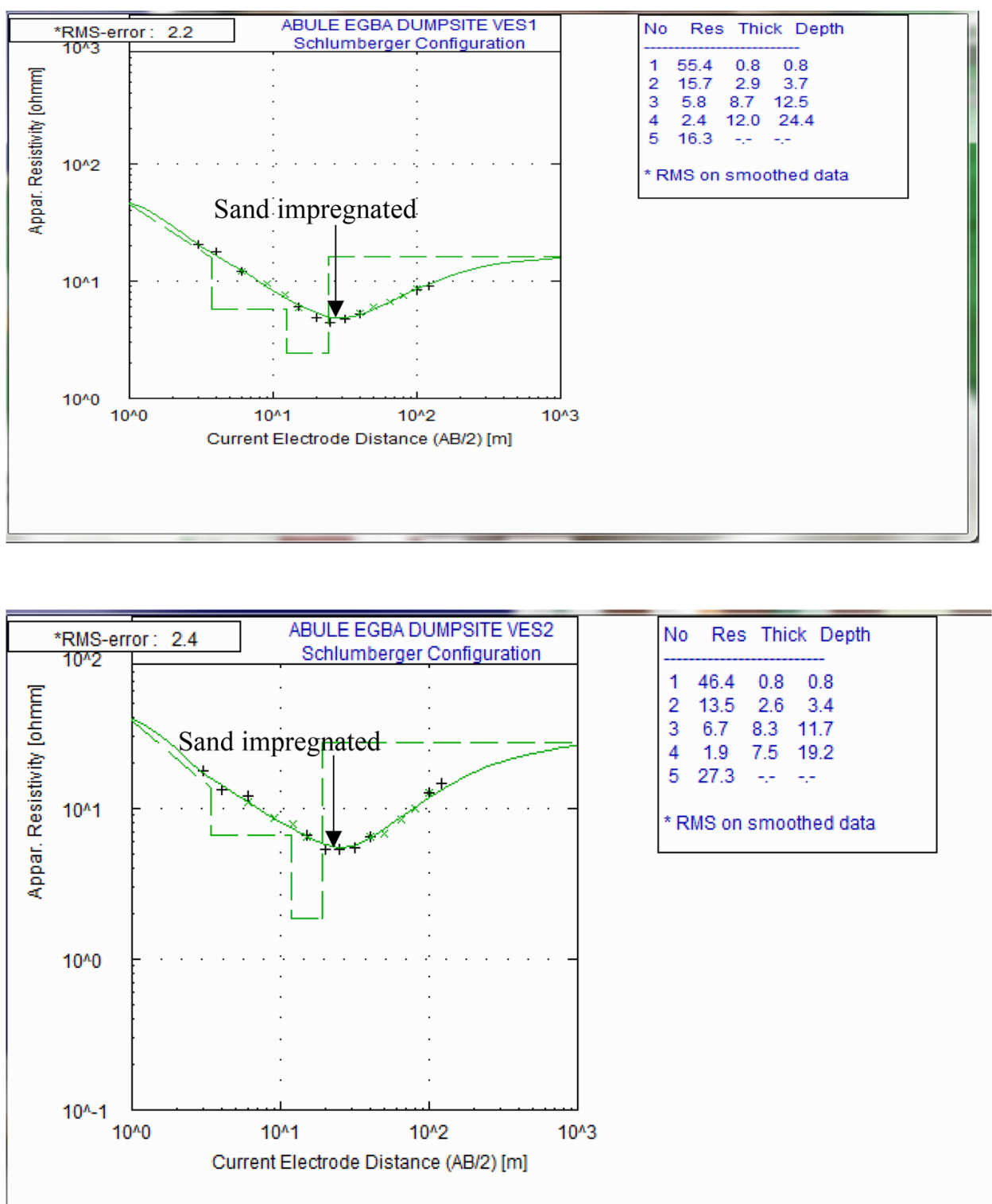

11; there are sandy clay and clay. The clay (third and fourth layer) with thickness range from 5.7 to $33.5 \mathrm{~m}$ might have impeded the infiltration of leachate into the underlain sand (fifth layer). The resistivity value of sand in fifth layer ranges from 114.6 to $520.7 \Omega \mathrm{m}$. The high resistivity value of sand is an indication of no leachate contamination.

The geoelectric section along traverse $C^{\prime} C^{\prime}$ is shown in Fig. 3c. It reveals four to five geoelectric layers with different resistivity values and thickness. The layers are topsoil, clayey sand, sandy clay, clay and sand. The first layer constitutes the topsoil with resistivity values ranging from 9.9 to $31.0 \Omega \mathrm{m}$ and layer thickness $0.7-2.7 \mathrm{~m}$. The second layer consists of clayey sand in VES $(13,15,17$, and 18) with resistivity values ranging from 14.5 to $52.7 \Omega \mathrm{m}$. The clayey sand is replaced with sandy clay in VES 14 with resistivity of $20.6 \Omega \mathrm{m}$ and thickness of $2.9 \mathrm{~m}$. The third stratum is sand/ clayey sand with resistivity ranging from 28.8 to $111.6 \Omega \mathrm{m}$ and thickness of 1.9-44.4 m. The fourth layer consists of sand (VES 17 and 18), sandy clay (VES 16), clayey sand (VES 13 and 15) and clay (VES 14), with resistivity values ranging (167.3-310.1 $\Omega \mathrm{m}, 28.4 \Omega \mathrm{m}, 77.8-81.1 \Omega \mathrm{m}$, and $21.7 \Omega \mathrm{m})$ respectively. The thickness of sand (VES 17 and 18) and clayey sand (VES 13 and 15) ranging from (10.8-20.4 m and $14.5-22.2 \Omega \mathrm{m}$,) but the thickness of sandy clay (VES 16) and clay (VES 14) could not be ascertained because current terminated within this zone. The low resistivity values associated with the sand is an indicative of contamination. The fifth layer is clay with resistivity ranging from 20.5 to $47.8 \Omega \mathrm{m}$ but the thickness could not be ascertained because the current terminated within this zone.

The geoelectric section along $\mathrm{DD}^{1}$ consists of six VES points (VES 19-24) with four to five geo-electric layers 

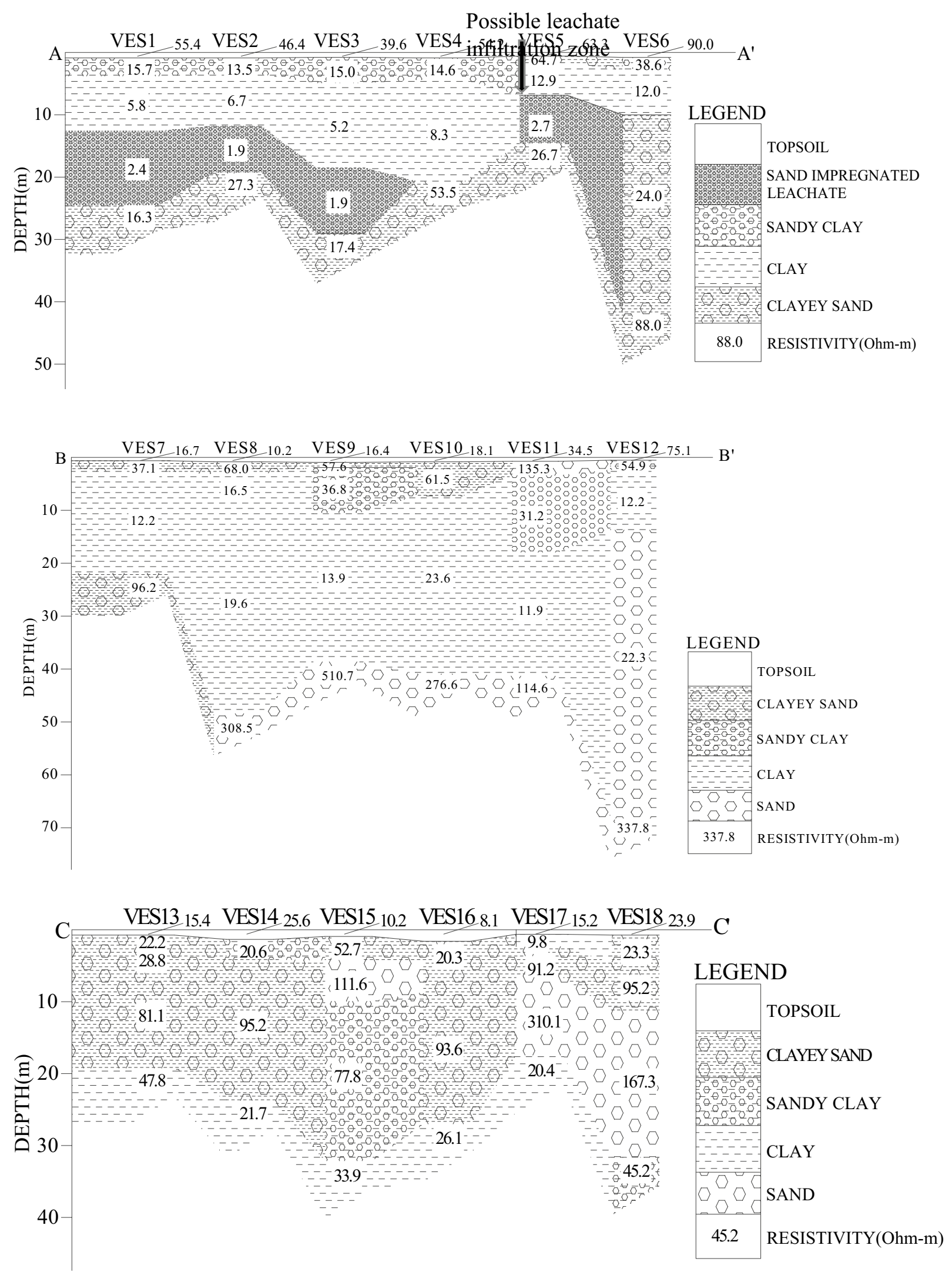

Fig. 3 a Geoelectric Section for VES 1-6. b Geoelectric Section for VES 7-12. c Geoelectric Section for VES 13-18. d Geoelectric Section for VES 19-24. e Geoelectric Section for VES 25-30 

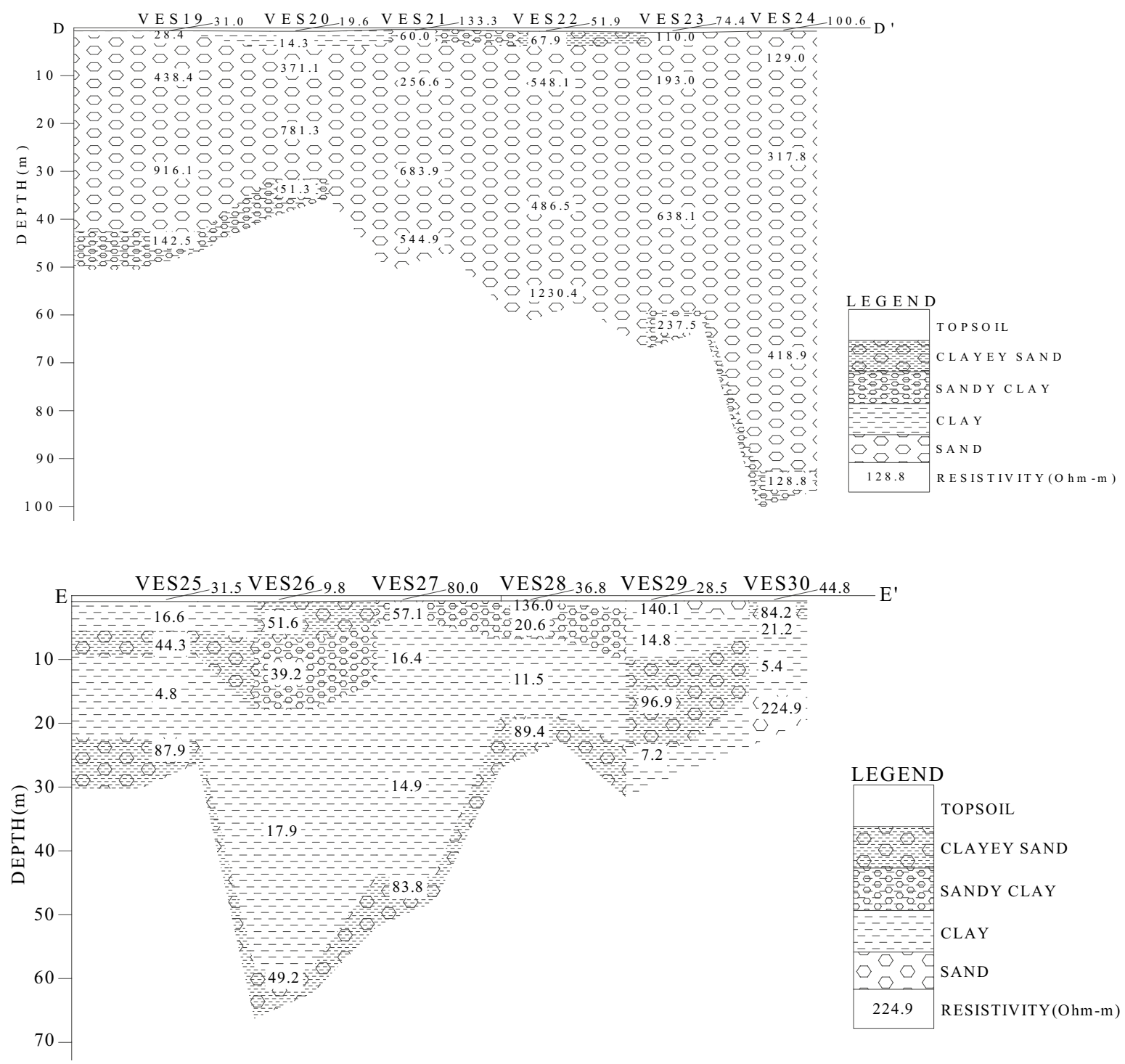

Fig. 3 (continued)

as shown in Fig. $3 \mathrm{~d}$. The layers correspond to the topsoil, clayey sand, sandy clay, and sand. The first layer is the topsoil with resistivity values ranging from 31.0 to $129.5 \Omega \mathrm{m}$ and layer thickness of $0.5-0.9 \mathrm{~m}$. The second layer consists of clay (VES 20,21,22) with resistivity and thickness values ranging from (14.3-67.9 $\Omega \mathrm{m}$, and 2.5-3.0 $\mathrm{m}$ respectively), sandy clay (VES 19) with resistivity and thickness value of (28.4 $\Omega \mathrm{m}$, and $1.1 \mathrm{~m}$ respectively), and sand (VES 23, 24) with resistivity and thickness values range (110.0-129.0 $\Omega \mathrm{m}, 2.4-10.1 \Omega \mathrm{m})$. The third stratum consists of sand with resistivity value range from 193 to $548.1 \Omega \mathrm{m}$ and layer thickness range from 6.5 to $93.2 \mathrm{~m}$. The fourth layer also consists of sand with resistivity values range from 143.5 to $1259.3 \Omega \mathrm{m}$ and layer thickness between 20.4 and $38.0 \mathrm{~m}$ but the thickness of layer four could not be ascertained in
VES (21 and 24) because the current terminated within this zone. The fifth layer composes of clayey sand and sand. The clayey sand is delineated in VES $(19,20$, and 24) with resistivity $142.5 \Omega \mathrm{m}, 51.3 \Omega \mathrm{m}$, and $143.5 \Omega \mathrm{m}$ respectively. The sand is delineated in VES 22 with resistivity 1230.4 and VES 23 with resistivity $237.5 \Omega \mathrm{m}$. The thickness of this layer could not be ascertained because the current terminated within this zone. The high resistivity value of the sand delineated reflects non-contamination.

The geoelectric section along $\mathrm{EE}^{1}$ reveals five geo-electric layers (Fig. 3e). The layers correspond to topsoil, clay, sandy clay, clayey sand and sand. The first layer constitutes the topsoil with resistivity values ranging from 9.8 to 103.9 $\Omega \mathrm{m}$ and thickness of $0.8-0.9 \mathrm{~m}$. The second consists of sandy clay with resistivity ranging from 16.6 to $140.1 \Omega \mathrm{m}$ 
and thickness of $0.4-5.9 \mathrm{~m}$. The third stratum also consists of sandy clay with resistivity value ranging from 14.8 to $44.3 \Omega \mathrm{m}$ and layer thickness of $2.7-11.0 \mathrm{~m}$. The fourth layer consists of clay with resistivity values ranging from 4.8 to $17.9 \Omega \mathrm{m}$. Beneath the VES 29 is clayey sand with resistivity of $96.9 \Omega \mathrm{m}$ and thickness of $13.4 \mathrm{~m}$. The fifth layer consists of clay sand (VES 25,26, 27,28) with resistivity (49.2-89.4 $\Omega \mathrm{m}$ ), clay (VES 29) with resistivity value of 7.2 $\Omega \mathrm{m}$ and sand (VES 30) with resistivity value of $224.9 \Omega \mathrm{m}$ but the thickness of this layer could not be ascertained because the current terminated within this zone. The low resistivity values (49.2-89.4) of sand (fifth layer) suggest that this layer is contaminated.

A correlation of the geoelectrical techniques and available borehole data is shown in Fig. 4. The result of the geoelectric section signifies topsoil with resistivity values ranging from 39.6 to $90.0 \Omega \mathrm{m}$ within the depth range of $0.5-0.8 \mathrm{~m}$ and the $2 \mathrm{D}$ inverted resistivity result indicates topsoil with resistivity values ranging from 20 to $54 \Omega \mathrm{m}$ within the depth range of $0-3 \mathrm{~m}$. Both the $2 \mathrm{D}$ resistivity and VES results show that the topsoil composing of clay and sandy clay agrees with the borehole data revealing clay along the profile. The second layer of the geoelectric section is clay/sandy clay with resistivity ranging from 13.5 to $64.7 \Omega \mathrm{m}$ and thickness range of $1.5-4.8 \mathrm{~m}$, this matches with the clay (Resistivity ranging from 7.7 to $13 \Omega \mathrm{m}$ and thickness range of 2.5-5.2 $\mathrm{m}$ ) delineated in the $2 \mathrm{D}$ resistivity section and which corresponds to the clay revealed by the borehole data. The third and fourth geoelectric layers (clay/sandy clay/sand impregnated with leachate) of resistivity ranging from 1.9 to $12.9 \Omega \mathrm{m}$ and thickness of 8.7-40.2 m corresponds to the 2D resistivity section (clay/ sand impregnated with leachate) with the resistivity values ranging from 1.9 to $4.7 \Omega \mathrm{m}$ and thickness of 7.5 to $15.0 \mathrm{~m}$. This equally agrees with the available borehole data (silty sand and sand). The fifth layer composes sand with

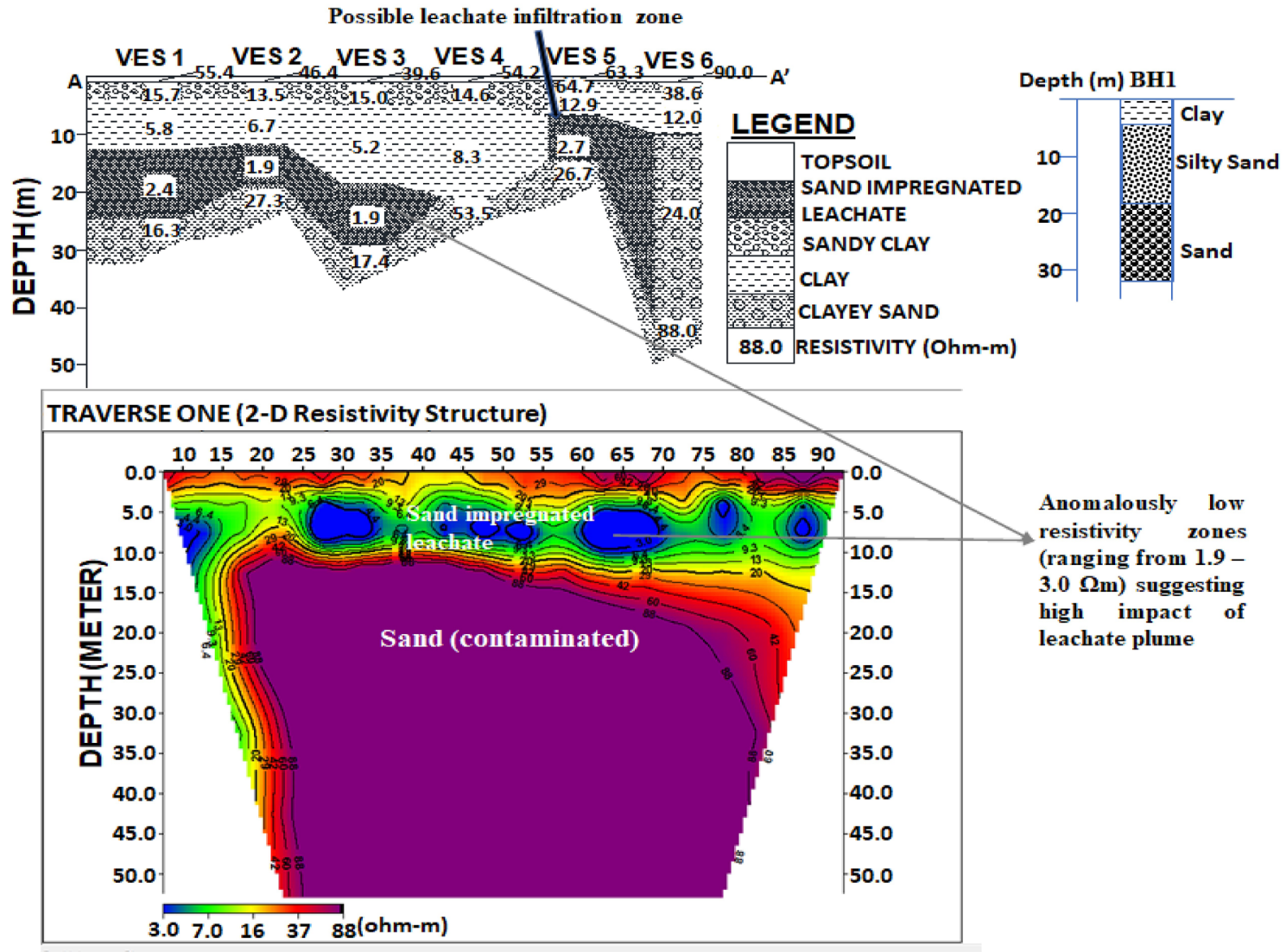

Fig. 4 The correlation of 1D, 2D resistivity structures and borehole data 
resistivity values ranging from 26.7 to $88 \Omega \mathrm{m}$. The anomalous low resistivity values $(1.9-88 \Omega \mathrm{m})$ of sand suggests high impact of leachate to about $40 \mathrm{~m}$.

\section{Discussion}

The low resistivity values of sand and clayey sand ranging from 1.9 to $88 \Omega \mathrm{m}$ as identified in Figs. $1 \mathrm{a}, \mathrm{b}, 3 \mathrm{a}, \mathrm{b}$ at depths range of 10-60 $\mathrm{m}$ when compared to the resistivity values of sand (195-1230 $\Omega \mathrm{m})$ reflected in Figs. 1d and $3 \mathrm{~d}$ at depths range of 7-55 m suggesting possible contamination of groundwater of the unconfined aquifers by infiltration of leachate. Studies have shown that groundwater could be taped at depth of about $5 \mathrm{~m}$ (or higher) in Lagos metropolis $[4,25,26]$. The presence of leachate at this depth within the study area might pose some threat to groundwater resources within the study area especially layers where unconfined aquifers are present. The resistivity values of $1.9-2.4 \Omega \mathrm{m}$ delineated as leachate contamination in this study is relatively lower than previous studies conducted around the dump site environment $[2,24,25]$. This reveals greater degree of decomposition of leachate and its migration trend. The low resistivity layer of sand unit impregnated with leachate (Figs. 1a and 3a) shows downward migration of leachate within the dumpsite and it agrees with leachate contaminated zone mapped by $[2$, $25,26]$. The thick clay layer ( $13 \mathrm{~m}$ ) (Figs. $1 \mathrm{~b}$ and $3 \mathrm{~b}$ ) is similar to zone interpreted as clayey material with low hydraulic conductivity [2] and thus, responsible for protecting the underlying aquiferous layer from leachates invasion from the surface. The low resistivity value of $14-9.8 \Omega \mathrm{m}$ of second layer identified in VES 16 and 17 respectively (Fig. 3c) could be attributed to leachate contamination from the overlying compacted dumps.

\section{Conclusions}

In this study, the electrical resistivity techniques were deployed to map the extent of leachate migration into the groundwater resources at Abule Egba Dumpsite, Lagos. The low resistivity sand and clayey sand ranging from 1.9 to $88 \Omega \mathrm{m}$ (VES 1-6) at depth range of $10-60 \mathrm{~m}$ suggest possible contamination of groundwater of the unconfined aquifers by infiltration of leachate. The study revealed high degree of decomposition of the leachate and its possible migration to a depth of about $30 \mathrm{~m}$. Hence, this study has shown the essence of continuous monitoring of leachate migration because its presence could pose some threat to groundwater resources within the dump site and its environment.
Availability of data and material Data can be made available on request.

\section{Compliance with ethical standards}

Conflict of interest The authors declare that they have no conflict of interest.

\section{References}

1. Abdulrahman A, Nawawi M, Saad R, Abu-Rizaiza AS, Yusoff MS, Khalil AE, Ishola KS (2016) Characterization of active and closed landfill sites using 2D resistivity/IP imaging: case studies in Penang, Malaysia. Environ Earth Sci 75:347. https://doi.org/10.1007/ s12665-015-5003-5

2. Adeoti L, Oladele S, Ogunlana FO (2011) Geo-electrical investigation of leachate impact on groundwater: a case study of Ile-Epo Dumpsite, Lagos, Nigeria. J Appl Sci Environ Manag 15(2):361-364

3. Adeogun OY, Adeoti L, Adegbola RB, Oyeniran TA, Alli SA (2019) Integrated approach for groundwater assessment in Yetunde Brown, Ifako, Gbagada, Lagos State, Nigeria. J Appl Sci Environ Manag 23(4):593-602

4. Ameloko AA, Ayolabi EA (2018) Geophysical assessment for vertical leachate migration profile and physiochemical study of groundwater around the Olusosun dumpsite Lagos, southwest, Nigeria. Appl Water Sci 8:142. https://doi.org/10.1007/ s13201-018-0775-x

5. Amusan AA, Ige DV, Olawale R (2005) Characteristics of soils and crops uptake of metals in municipal waste dumpsites in Nigeria. J Hum Ecol 17(3):167-171

6. Ayolabi EA, Oluwatosin LB, Ifekwuna CD (2015) Integrated geophysical and physiochemical assessment of Olushosun sanitary landfillsite, southwest Nigeria. Arab J Geosci 8(6):4101-4115

7. Billman HG (1992) Offshore stratigraphy and paleontology of the dahomey embayment, West African. NAPE Bull 7(2):121-130

8. Cardarelli E, Di Filippo G (2014) Integrated geophysical surveys on waste dumps: evaluation of physical parameters to characterize an urban waste dump (four case studies in Italy). Waste Manag Resour 22(5):390-402

9. Calson N, Hare J, Zonge K (2001) Buried landfill delineation with induced polarization: progress and problems. https://doi. org/10.4133/1.2922924

10. Dadras M, Ahmad RM, Farjad B (2010) Integration of GIS and multicriteria decision analysis for urban solid waste management and landfill Site selection in Bandar Abbas city, south of Iran. Int Geoinformat Res Dev J 1(2):1-14

11. De Donno G, Cardarelli E (2017) Tomography inversion of time domain resistivity and chargeability data for the investigation of landfills using a prior information. Waste Manag Resour 59:302-315

12. Degueurce A, Clement R, Moreau S, Peu P (2016) On the value of electrical resistivity tomography for monitoring leachate injection in solid state anaerobic digestion plants at farm scale. Waste Manag Resour 56:125-136

13. Effat HA, Hegazy MN (2012) Mapping potential landfill sites for North Sinai cities using spatial multicriteria evaluation. Egypt J Remote Sens Space Sci 15:125-133

14. El Maguiri A, Kissi B, Idrissi L, Souabi S (2016) Landfill site selection using GIS, remote sensing and multicriteria decision analysis: case of the city of Mohammedia. Bull Eng Geol Environ, Morocco. https://doi.org/10.1007/s10064-016-0889-z 
15. Koefoed O (1979) Geosounding principle, resistivity sounding measurements. Elsevier Scientific Publishing, Amsterdam

16. LAWMA (2018) Waste Dumped by land filled for the year. http:// www.lawma.org/databank/waste\%20data\%202018

17. Longe EO, Enekwechi LO (2007) Investigation on potential groundwater impacts and influence of local hydrogeology on natural attenuation of leachate at a municipal landfill. Int J Environ Sci Technol 4(1):133-140

18. Majolagbe AO, Kasali AA, Ghaniyu LO (2011) Quality assessment of groundwater in the vicinity of dumpsites in Ifo and Lagos, Southwestern Nigeria. Adv Appl Sci Res 2(1):29-89

19. Mor S, Ravindra K (2016) Leachate characterization and assessment of groundwater pollution near municipal solid waste landfill site. Environ Monitor Assess 118(1):435-456

20. Mota R, Monteiro Santos FA, Mateus A, Marques FO, Goncalves MA, Figueirasc J, Amaral H (2004) Granite fracturing and incipient pollution beneath a recent landfill facility as detected by geoelectrical surveys. J Appl Geophys 57:11-22

21. Naudet V, Gouiry JC, Girard JF, Mathieu F, Saada A (2014) 3D electrical resistiity tomography to locate DNAPL contamination around a housing estate. Near Surface Geophys 12(3):350-351

22. Okoli CC, Cyril A, Itiola OJ (2013) Geophysical and Hydrogeochemical Investigation of Odolomi Dumpsite in Supare-Akoko, Southwestern Nigeria. Pac J Sci Technol 14(1):492-504

23. Ogilvy R, Meldrum P, Chambers J, Williams G (2002) The use of $3 \mathrm{D}$ electrical resistivity tomography to characterize waste and leachate distribution within a closed landfill, Thriplow, UK. J Environ Eng Geophys 7(1):11-18

24. Ogungbe AS, Onori EO, Olaoye MA (2012) Application of electrical resistivity techniques in the investigation of groundwater contamination: a case study of Ile - Epo Dumpsite, Lagos, Nigeria. Int J Geomat Geosci 3(1):30-41
25. Oladapo MI, Adeoye-Oladapo OO, Adebobuyi FS (2013) Geoelectrical study of major landfills in the Lagos Metropolitan Area, Southwestern Nigeria. Int J Water Resour Environ Eng 5(7):387-398

26. Olowofela JA, Akinyemi OD, Ogungbe AS (2012) Imaging and detecting underground contaminants in landfill sites using electrical impedance tomography (EIT): a case study of Lagos, Southwestern, Nigeria. Res J Environ Earth Sci 4(3):270-281

27. Orelana EA, Mooney HM (1969) Master tables and curves for Vertical Electrical Sounding over layered structures. Intergencia, Madrid, $p 159$

28. Oyeyemi KD, Aizebeokhia AP, Ede AN, Rotimi OJ, Sanuade OA, Olofinnade OM, Akhaguere OA, Attat O (2019) Investigating the near surface leachate movement in an open dumpsite using surficial ERT method. IOP Conf Ser Mater Sci Eng 640:012109. https://doi.org/10.1088/1757-899x/640/1/012109

29. Raji WO, Adeoye T (2016) Geophysical mapping of contaminant leachate around a reclaimed open dumpsite. J King Saud UnivSci. https://doi.org/10.106/j.jksus.2016.09.005

30. Ramalho EC, Dill AC, Rocha R (2013) Assessment of leachate movement in a sealed landfill using geophysical methods. Environ Earth Sci 68(343-354):1742-1748

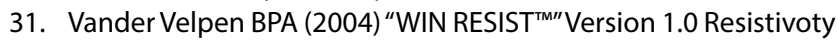
Depth Sounding Interpretation Software. M.Sc Research Project, ITC, Delf Netherland

Publisher's Note Springer Nature remains neutral with regard to jurisdictional claims in published maps and institutional affiliations. 